\title{
Household language, residential segregation and social mobility: continuity and change in eThekwini, South Africa
}

\author{
Simon Bekker ${ }^{1}$ and Lloyd Hill
}

\author{
Department of Sociology and Social Anthropology \\ University of Stellenbosch, Email: sb3@sun.ac.za, \\ Tel: +27-21-808 2099, Fax: +27-21-808 2143
}

\begin{abstract}
This article uses South African census data for 1996, 200I and 20II to explore the relationship between language and social mobility in the metropolitan region of eThekwini (including what was previously known as Durban). We focus particular attention on variables selected to shed light on residential segregation and social mobility, such as education level, income, race and in-migration. Data on adults at ward level (using 201 I ward boundaries) in eThekwini is used to develop a comparative spatial context for this analysis. Our main finding is that English appears in eThekwini to be the household language of the social elite as well as the language of upward mobility and empowerment.
\end{abstract}

Keywords: language; migration; urbanisation; eThekwini; South Africa

\section{Résumé}

Cet article utilise des données de recensement sud-africains en $1996,200 \mid$ et 201 I pour explorer la relation entre la langue et la mobilité sociale dans la région métropolitaine d'eThekwini (y compris ce qui était auparavant connu sous le nom de Durban). Nous nous concentrons en particulier sur les variables sélectionnées pour éclaircir la ségrégation résidentielle et la mobilité sociale, indiqués par le niveau d'éducation, le revenu, la race et à la migration. Les données sur les adultes au niveau de la paroisse ('ward', en 20II) dans eThekwini sont utilisé pour développer un contexte spatial comparative pour cette analyse. Notre principale conclusion est que l'anglais apparaît dans eThekwini à être la langue des ménages de l'élite sociale ainsi que la langue de la mobilité sosiale vers le haut.

Mots-clés: langue; migration; urbanisation; eThekwini; Afrique du Sud

\section{Introduction}

After the end of apartheid, South African cities were released from their legal racial barriers and legislation was introduced to desegregate urban South Africa. In debates on whether progress has been made, urbanists have focused on two divides within the city: the racial divide in urban space, and the divide between the elite and affluent residents, on the one hand, and the working and underclasses, typically fragmented, on the other (Bekker \& Leildé 2006, Leildé 2008).

In this article we explore how language correlates with continuities and changes to residential segregation - the racial divide - and to upward mobility - the class divide - in the metropolitan region ('metro') of eThekwini. This will be done over the fifteen year period between 1996 and 2011 by comparing metro-wide trends with variation at submetropolitan level. Upward mobility will be identified by calculating shifts in the socio-economic status (henceforth 'SE status') of adult residents (employing (I) the proportion of adults reporting post-matric educational qualifications; and (2) the proportion of adults reporting individual incomes exceeding that of $\mathrm{RI} 2800 \mathrm{pm}$ in 20II). Residential segregation will be identified by considering how the racial profiles of adult residents have changed over the last fifteen years. In the third place, migration flows into the metro and at sub-metropolitan level will be identified to enable an analysis of shifts in language, SE status and racial profiles at these two levels. The primary source of data will be census results for 1996, 200 I and 20I I, aggregated for adults at metro and at ward levels.

\section{Literature Review and Theoretical Framework eThekwini metro overview \\ eThekwini was established as a metropolitan council and municipality in 200 I through the amalgamation of a number of municipal structures in the city of Durban and its periphery. Demographically, it is the third largest metropolitan municipality in the country}


with a population of three and a half million (in 20I I). Spatially, its zone of jurisdiction covers some 2300 square kilometres - the largest metro in the country - and stretches from Umkomaas in the south to Tongaat in the north and to Cato Ridge in the west.

By representing this zone of jurisdiction as comprising four areas - the Southern, Central and Northern spatial districts on the coast, and the Western spatial district in the interior of the province of KwaZulu-Natal (KZN) (Draft IDP 20/3/I4), it is possible to illustrate how this new municipal metro was planned to establish a new representative centralised authority aimed at promoting greater equity in service delivery to many more than the residents of the former city of Durban (which was situated principally in the Central district). This metro council is made up of two groups of councillors: those elected by proportional representation and those elected by voters within each ward of the metro.

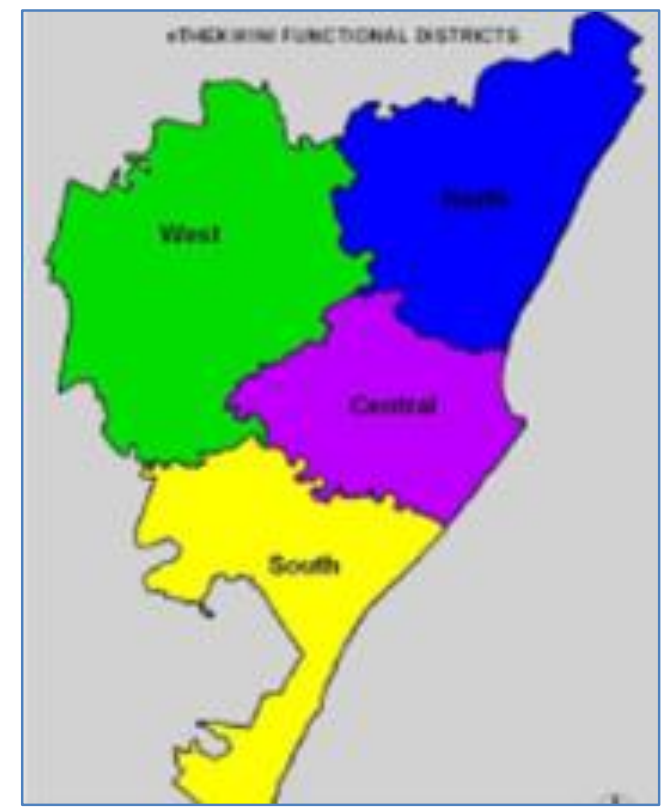

Figure I: eThekwini Functional Districts ${ }^{2}$

The KZN provincial administration ${ }^{3}$ estimates that approximately one third of eThekwini metro ought to be considered rural and another one third periurban, leaving the final third alone to be classified as an urban built environment.

- This urban built environment is principally found in the Central district as well as within the corridors of the coastal N2 freeway and interior N3 freeway. The Central district is accordingly the urban core of the metro in which more than one third of the population reside on less than $30 \%$ of the surface area.

- The Northern district - to the north of the Umgeni River - includes the township of KwaMashu, the suburb of Umhlanga and the settlement of Tongaat as well as large swathes of rural sugarcane plantations. Some $30 \%$ of the metro's population resides here.

- In the Southern district accommodating some $20 \%$ of the metro population, coastal towns such as Amanzimtoti and Umkomaas are complemented by former KwaZulu homeland townships as well as peri-urban residential areas in which traditional authority and customary law exist parallel to ward councillor representation and metropolitan authority.

- In the fourth place, the Western district in the interior covers a little more than a third of the metro's surface area and accommodates just $16 \%$ of its population. Most of this area is also characterised by parallel authorities. Its smaller population lives under peri-urban conditions where a scattering of homesteads rather than housing within a planned built environment is the norm.

Physically, eThekwini's surface area is characterised by broken land comprising many hills, valleys and steep slopes - epitomised in the touristassociated Valley of 1000 Hills. The two freeways mentioned above (the N2 along the coast and the N3 connecting Durban to Gauteng via Pietermaritzburg) represent relatively well-performing multi-purpose corridors that integrate - spatially - residential, economic and service functions.

The metro is the largest municipality in the province and made up one third of KZN's total population in 201l. In terms of race ('population group'), the metro's three and a half million residents may be broken down into $74 \%$ African (overwhelmingly Zulu-speakers), I7\% Indian and 7\% White ${ }^{4}$. The latter two groups were in 201I overwhelmingly English-speaking. Over the past fifteen years, the population living in the metro area grew substantially faster over the 1996-200I intercensus period - at $2.6 \%$ - than during the latter decade of $200 \mathrm{I}$ to $20 \mathrm{II}$ when the annual rate of increase fell to $1.7 \%$.

\section{A brief history of the metro and of its main languages}

During the twentieth century, the city of Durban's development has been intimately tied up with the growth of Johannesburg and Gauteng, some 600 kilometres away in the interior of South Africa. Gold mining and the economic expansion of Johannesburg required a harbour to expedite the flow of its exports to global markets. Durban fulfilled this role throughout the twentieth century. eThekwini, while 
continuing to play this role at the start of the twentyfirst century, has also expanded its manufacturing base to become the second largest among metros in the country. It also has an important financial and business sector, which includes tourism as a significant component. Its GDP was the third largest of the six metros in 201 I, behind Johannesburg and Cape Town ${ }^{5}$.

In the first decades of 20th century, Durban's economy centred on the harbour, leading to flat land close by becoming occupied both by single African male migrants as well as by Indian market gardeners. Since relatively little industrialisation or formal municipal government and housing provision took place before the 1940s, the Second World War proved to be a major impetus for urban development: the manufacturing sector grew and significant streams of urbanising Africans - including a larger proportion of women - entered the city. Urbanising Indians who tended to migrate to the city with their whole families were South African born, the children or grandchildren of indentured workers from India. White in-migrants came from Johannesburg or Cape Town and were predominantly English-speaking. During the first postIIWW decade, separate municipal administrations for White, Indian and African residents, institutions already implicit in earlier municipal government, were established by legislation and implemented. The segregation of residential areas for these groupings into "group areas" often necessitating forced removals (Freund 2007, Freund \& Padayachee 2002, Maylam \& Edwards 1996).

The efficient application of pass laws intended to control the flow of rural Africans into the city became a higher priority to the apartheid government as informal settlements close to the burgeoning industrial and commercial areas of the city developed. Single men hostels and shack settlements within the city, and townships - such as KwaMashu within the homeland of KwaZulu were constructed and these residential populations grew rapidly in the 1960s, 1970s and 1980s.

By the 1970s and 1980s, residential segregation in the city of Durban - then situated in the province of Natal - was planned to provide group areas for Indian and White (and Coloured) residents whilst the homeland of KwaZulu, falling under the Inkatha Cultural Movement, latterly the Inkatha Freedom Party (IFP) government, housed most Africans working in the city, many living in informal settlements in the peripheral regions of greater Durban. An independent state organisation, the Port Natal Bantu Affairs Administration Board was responsible for 'black affairs' outside KwaZulu and was faced both with rent boycotts regarding its service delivery as well as with growing 'grey areas' in the central city where Africans occupied flats and other types of accommodation illegally in White Group Areas (Bekker \& Humphries 1985). Many affluent White families quit the centre for elite residential areas elsewhere. Most Indian families were forced to relocate to segregated public housing estates (in Phoenix and Chatsworth as examples). In short, the 1980s in Durban were turbulent and often violent years including not only mass meetings, boycotts and demonstrations within the city but a low level civil war between the IFP, the ruling party in the homeland of KwaZulu, on the one hand, and parties aligned to the ANC-in-exile, on the other. Between 1986 and 1995, in the province, some 15 000 deaths resulted from this latter conflict (Bekker \& Louw 1992).

Such was the spatial legacy of residential separation that the new city government of Durban inherited in 1995 and which was passed on to the eThekwini metropolitan authority in $200 \mathrm{I}$. Since its establishment, eThekwini municipality has rolled out municipal services inter alia to households in periurban (particularly former homeland) areas which include potable water and electricity (both with an initial free capped quantity) as well as improved transport into the central region of metro where most employment opportunities are located.

\section{The social significance of language}

A recent assessment of " $(\mathrm{t})$ he rich and diverse literature on race and class in post-apartheid South Africa has generally drawn a picture of, at best, no progress towards social and economic transformation and, at worst, increasing inequality and fragmentation." The authors, Schensul and Heller, then continue by referring to "Seekings's and Nattrass's Class, Race and Inequality in South Africa (2005), which argues that post-apartheid economic and social policies deracialized but nonetheless preserved the class divisions of the late apartheid distribution regime by extending it beyond its White historical base to include a small, emerging African middle class and the organized African working class." (Schensul \& Heller 20II: 79). One aspect of emerging post-apartheid urban class divisions that has received relatively little attention is language. It is appropriate here to reflect briefly on the history of the main languages, first, in Durban and, subsequently, in eThekwini.

Named after an English governor of the Cape Colony in the nineteenth century, Durban from its foundation received European colonists who were predominantly English-speaking. Though some Afrikaans-speaking migrants did settle in the city, their numbers were always small and their linguistic 
influence minimal. English has remained the dominant language of trade, of education and of mass media throughout Durban's history. It is also the dominant language of the White minority in eThekwini today.

Indian indentured labourers arrived in the latter half of the nineteenth century and were put to work on sugarcane and cotton plantations. They were accompanied by a smaller number of 'passenger' (non-indentured) Indian migrants. These immigrants spoke a number of the languages of the Indian subcontinent, Tamil, Hindi, Telugu, Urdu and Gujarati in particular. For generations, these languages were retained as home languages and it was predominantly men sharing a work environment with non-Indians who acquired English as a second language. A dramatic linguistic shift in the Indian population which is displayed below in Table I, took place in the latter half of the twentieth century. It is explained as follows:

By the 1930s the pattern of language learning had not changed much from nineteenth-century trends. English was learnt as a second or third language outside the home (in classrooms or, in the case of large numbers who had no schooling, either at work or not at all). By the late 1950s, when education facilities had improved, English began to be introduced in the home and neighbourhood by children. In some homes a rapid inversion of roles took place... In the 1960s and 1970s English became the first language of a majority of Indian schoolchildren. A process of shift is under way, with the Indian languages surviving with some difficulty. (Mestrie 2004: 340)

Most Africans speak Zulu (or a related Nguni language) in eThekwini. This is a situation that has not changed significantly over the past half-century (though the acquisition of English as a second language has become a significant marker of access to the labour market and of upward mobility (Casale \& Posel 20I I). It is appropriate here to note that the change in nomenclature introduced by the metro council for both the city (from Durban to eThekwini) as well as for numerous streets, exhibits not only a symbolic change of ideology in city government but also a shift in visual prominence from the English to the Zulu language.

Table I below compares home language reported in 1951 in Durban to that reported in 2011 in eThekwini.

Table I: Home language by race in Durban (I95I) and eThekwini (20I I $)^{6}$

\begin{tabular}{|c|c|c|c|}
\hline Race & Home language & 1951 census & 2011 census \\
\hline (all respondents) & & $\%$ total response & $\%$ total response \\
\hline African & English & $0.04 \%$ & $5 \%$ \\
\hline African & Zulu & $86 \%$ & $85 \%$ \\
\hline African & All other languages & - & $11 \%$ \\
\hline African & other Nguni & $13 \%$ & -- \\
\hline Indian & English & $6 \%$ & $95 \%$ \\
\hline Indian & Zulu & $0 \%$ & $1 \%$ \\
\hline Indian & All other languages & -- & $11 \%$ \\
\hline Indian & Indian subcontinent & $92 \%$ & -- \\
\hline White & English & $84 \%$ & $80 \%$ \\
\hline White & Zulu & $0 \%$ & $1 \%$ \\
\hline White & All other languages & -- & $18 \%$ \\
\hline White & Afrikaans & $14 \%$ & -- \\
\hline
\end{tabular}


This table provides a broad comparison between two historical periods, but given that Durban has been replaced by a qualitatively different metropolitan entity, our focus now shifts to a more detailed analysis of the language and socio-spatial inequality in eThekwini.

\section{Data and Methods}

\section{Census data on "household language"}

In the three post-apartheid censuses, questions on language refer to speech in the context of a "home" (1996) or a "household" (200I and 20II). Accordingly, we have decided to refer to the relevant census data as 'household language' and to intercensus trends as "language shifts". Here "shift" denotes a "geographical shift", or a change in the number of respondents - within a household, ward or other territorial unit - who have reported using an official language as the main means of household communication. More wide-ranging discussion of the implications of this use of language data (as well as the fact that the first two censuses refer to "home" or "household" language in the singular and the third refers to two languages) may be found in an earlier publication employing the same methodology and applied to the Cape Town metropolitan area (Hill \& Bekker 20I4).

Since the object of analysis is to assess how language correlates with residential segregation and upward mobility in a metropolitan region, the selection of sub metropolitan case studies comprising one or more contiguous wards - will be guided both by language trends over the 15 year inter-census period as well as by the location of these cases relatively close to or far from the primary development corridors of the metro, spatially conceptualised as two well-performing arms that are physically integrated (Hill \& Bekker 20I4: 670). The latter criterion encapsulates issues relating to proximity of employment and of educational opportunities as well as straightforward access to commercial and trading sites. In turn, these factors influence residential property prices.

Using ward-based census data in eThekwini and seven sub-metropolitan case studies

For the purpose of our analysis we selected seven sub-metropolitan case studies within the metro and used these - together with the metro itself - to identify a number of language trends during the period identified. These will lead to the main analysis: the correlation of household language with continuities and changes to residential segregation and to upward mobility in the metropolitan region ('metro') of eThekwini.

Our analysis proceeds in two stages. We begin by focusing on the census statistics for the two household languages that predominate in eThekwini: English and isiZulu. These two languages are used to produce ward-based profiles of eThekwini for 1996, $200 \mathrm{I}$ and 20II. Drawing on patterns of language continuity and change (between 1996 and 20I I), we analyse trends evident in these profiles and use these as the basis for a more focused study of the relationship between language, SE status and race in seven sub-metropolitan case studies in the metro. The case study areas comprise single wards (and in one case, three contiguous wards) that share one or more of the language criteria identified in the initial stage of the analysis.

The second stage of the analysis therefore takes the form of a cross-tabulation (using 201I data in SuperCROSS) of the seven ward-based cases and three sets of census variables: SE status, race ('population group') and in-migration. Two census variables - individual monthly income and level of education - are used together to serve as an approximation of SE status in the adult populations.

\section{Selection of seven eThekwini case studies}

Two criteria were employed to guide our selection. In the first place, five of the seven cases were selected within or close to the N2 and N3 development corridors whilst the remaining two (Umbumbulu-Nkomokazi in the south and UmgeniImbozamo in the western interior) were selected from the metro's peri-urban periphery. In the second place, six of the seven cases were selected because they show no change in household language status over the past fifteen years. These six cases include three (Gillitts-Kloof, Westcliff-Bayview, and Umhlanga) situated in central metro areas that have experienced significant urban development over the period. The one case of significant household language change - Umdloti-Tongaat - is situated in the far north of the metro and comprises two urban settlements surrounded by rural areas.

We introduce the seven case studies below by outlining a number of pertinent features of the wards that make up the case before identifying the language status shared by these wards during the 1996-20II period. Map 4 locates the cases within eThekwini.

Case I: Gillitts-Kloof consists of a single ward situated in the interior of the metro close to the N3 corridor. It developed as an elite white residential neighbourhood with low population density and a temperate climate. Before 1994, it was declared a 
white Group Area in the province of Natal. It has retained its predominant English-language status over the past fifteen years.

Case 2: Umdloti-Tongaat consists of a single ward situated in the far north of the metro. It comprises two urban places: Tongaat in the interior surrounded by rural sugarcane plantations and Umdloti, a small upmarket coastal resort characterised by ribbon highrise apartment block development parallel to the coastline. Before 1994, it fell within the province of Natal and included both white as well as Indian Group Areas. Its language status has shifted from predominant English-speaking ( $>66 \%$ ) to an isiZuluEnglish mix (neither language $>49 \%$ ) over the past fifteen years.
Case 3: Umbumbulu-Nkomokazi consists of a single ward situated in the southern-interior region of the metro. It is a peri-urban area in which parallel traditional and metro authority exists. Anecdotal evidence suggests that the traditional authority (the inkhosi) takes responsibility for land tenure issues (applying what could be called a 'living' customary tenure approach) whilst the metro authority (via the ward councillor) takes responsibility for service delivery, water, sewage, electricity and transport in particular ${ }^{7}$. Such dual authority may lead to tension and conflict (Palmary 2004). Before 1994, it fell within the homeland of KwaZulu. It has retained its predominant isiZulu-language status over the past fifteen years. 


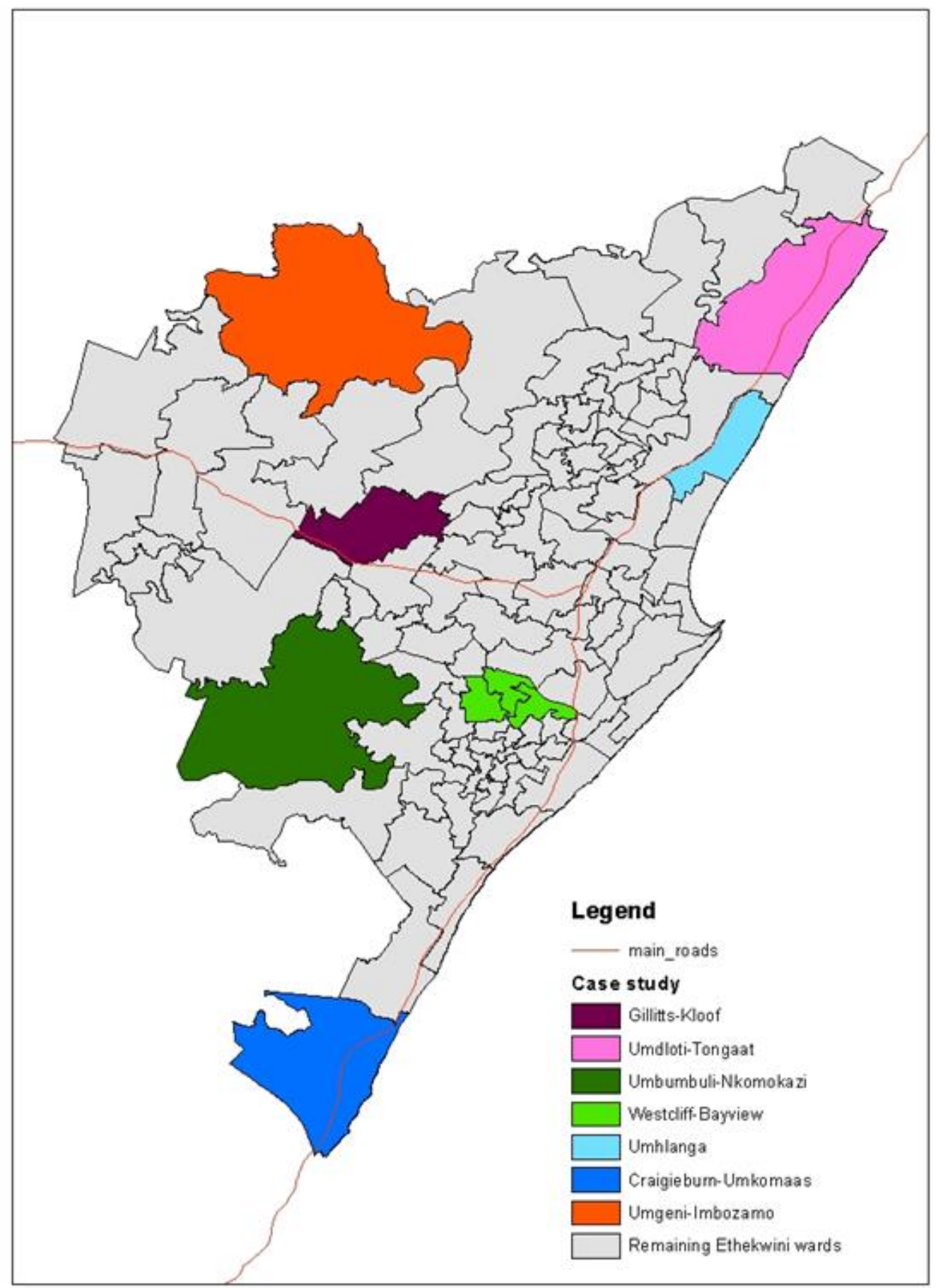

Figure 5: Case Study Areas

Case 4: Westcliff-Bayview is demarcated by three wards situated in the heart of the inner city. It contains Chatsworth, a former Indian Group Area that was one of the housing estates to which many Indian residents of Durban were relocated in the years before the 1990s. In the words of Desai (2014: 46) reflecting on the history of Chatsworth:

Ancient traditions still live here, contesting and accommodating the new. The iconic Hare Krishna temple shares a space with older smaller brightly hand-painted ones. Pentecostalism is all the rage among the young, while the candles of the traditional churches light up empty pews... And in the flat-lands and shack settlements, Indians and Africans seek to make everyday life as borders blur...

This area has retained its predominantly Englishlanguage status over the past fifteen years.

Case 5: Umhlanga is demarcated by a single ward situated north of the Umgeni River within the N2 corridor and on the coast. In the second half of the twentieth century, flats and time share units for the wealthy, both from Durban as well as Johannesburg, were constructed. After 1994, the ward has evolved into an elite upmarket residential centre focused on a modern mall, appropriately named the Gateway. It 
has retained its predominant English-language status over the past fifteen years.

Case 6: Craigieburn-Umkomaas is demarcated by a single ward situated on the southern boundary of the metro. The former white coastal town of Umkomaas and inland service town of Craigieburn were complemented before 1994 by the peri-urban area of Magabheni - forming, in the language of the time, the association of 'town and location', a common occurrence on the South Coast where 'town' fell within Natal and 'location' within KwaZulu. Today, Magabheni shares parallel traditional and metro authority with two of our other selected case studies. The headquarters of South African Pulp and Paper Industries (SAPPI) KZN is located within the ward as is one of its principal pulp and paper mills. The ward has retained its majoritarian isiZulu-language status (between 50 and $66 \%$ isiZulu) over the past fifteen years.

Case 7: Umgeni-Imbozamo is demarcated by a single ward situated in the western interior of the metro close to the Inanda dam. As with the case of Umbumbulu-Nkomokazi, it is a peri-urban area in which parallel traditional and metro authority exists, in which both amakhosi and a ward councillor operate. Before 1994, it fell within the homeland of KwaZulu. It has retained its predominant isiZululanguage status over the past fifteen years.

\section{Discussion of results}

\section{Metro-level household language trends}

The $201 \mathrm{I}$ census reported that some 2394391 adults (aged 20 or above) resided in eThekwini. Of these, 29\% were English-speakers and 58.8\% isiZulu-speakers and the remainder - some I2\% indicated other languages as their household language. No other language scored $5 \%$ or more of the total with isiXhosa emerging as the highest, at $4.1 \%$ (foreign languages made up 3.2\%). Accordingly, we decided to focus exclusively on the two main reported household languages.

These proportions have not remained static within the adult population over the last fifteen years. In 1996, English-speakers made up $36 \%$ and Zuluspeakers $57 \%$ of the adult population (of I8I $3175)$. On the other hand, when compared to Cape Town (Hill \& Bekker 20l4), annualised increases both within household language groupings as well as metro-wide are low, reflecting differences in gross migration flows into these two metros:

- the English-speaking adult population revealed low rates of increase - annualized rates of $0.43 \%$ during the $1996-200 \mid$ period and of $0.48 \%$ during the 200I-20I I period (Census totals of adult populations were 648838 in 1996, 662639 in 2001 and 694I43 in 20II).

- the Zulu-speaking adult population revealed a high rate of increase of $3.5 \%$ pa during the 1996$200 \mathrm{I}$ period and a lesser rate of $1.58 \%$ pa during the 200 I-20II period (Census totals of adult populations were 1035186 in 1996, 1216530 in 2001 and I4088 I 3 in 20I I).

- though the numbers are small, rates of increase for both adult isiXhosa speakers and foreign language speakers were positive over this fifteen year period, pointing in all probability to rising in-migration streams from the Eastern Cape and from foreign countries.

\section{Ward-level language trends}

We now turn to a spatial representation at ward level of the two main languages in the metro for the census years 1996, 200I and 20II. The three colourcoded maps below identify the main household language(s) in each of the 103 wards of eThekwini (as delineated in 201 I). This colour-coding comprises five categories. In the first place, two shades of the same colour are used for each of the two languages in order to distinguish between a ward within which one language was selected by more than two thirds of the adult population (dubbed 'predominant' and denoted by the darker shade) and wards where that language was selected by a majority comprising between 50 and $66 \%$ of the adult population (dubbed 'majority' and denoted by the lighter shade). The remaining category identifies wards in which no language is majoritarian and hence in which both language groups are identified (dubbed 'plurality' and denoted by a mix of the two associated colours).

\section{A preliminary analysis of these maps reveals three broad trends:}

Trend I: Over the past fifteen years, isiZulu has remained the "predominant" language over more than half of the surface area of eThekwini, spatially forming a broad semicircle from Inanda and KwaMashu in the northern interior of the metro to Umbumbulu in the south. Many of the wards that make up this semicircle are either peri-urban or rural. The fact that very few are situated on the coastline is conspicuous. More generally, most wards in the metro do not reveal a language shift.

Trend 2: A number of wards in the Central spatial district, the city core, whilst generally maintaining an English-speaking adult majority, reveal a trend toward a greater proportion of isiZulu speakers who have taken up residence in this district. Since this core includes large numbers of working class residents, this trend may well be seen to represent the 
incorporation of a growing number of Zulu-speaking workers into these inner city neighbourhoods.

Trend 3: A number of wards in the Northern spatial district - comprising urban settlements north of the Umgeni river - reveal the most significant language shift - from predominantly English-speaking to a mix of wards in which either English or Zulu emerge as majoritarian (rather than predominant) as well as wards where these two languages make up a "plurality". New middle and up-market urban residential developments initiated by Tongaat-Hulett, a local company, is one reason for this shift. Simultaneously, there are a few wards - both in this district as well as inland on the N3 freeway - that have retained their predominant English-language status over the entire period.

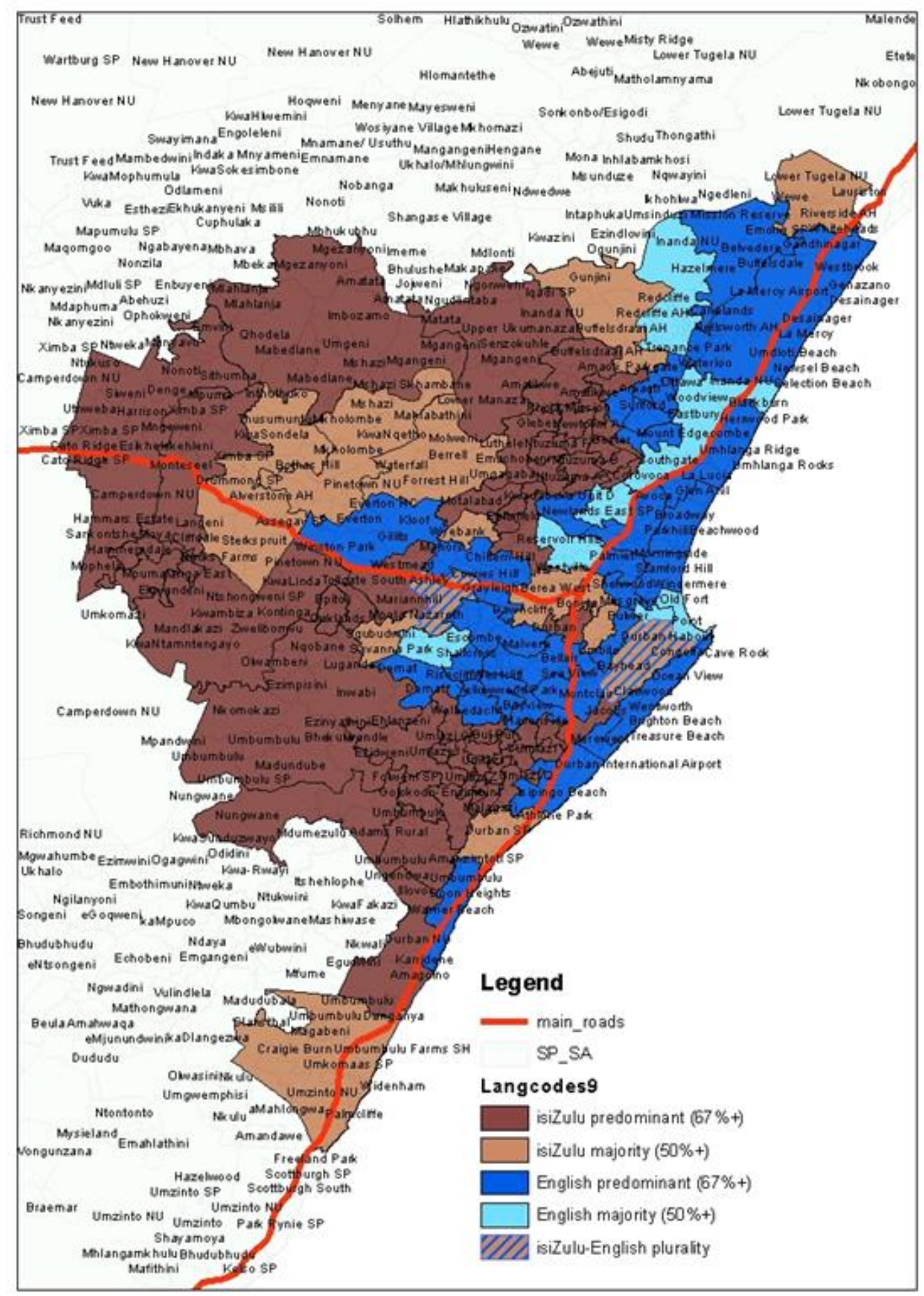

Figure 2: Household languages in eThekwini (1996 Census) 
African Population Studies, Vol 30, No 2, 2016

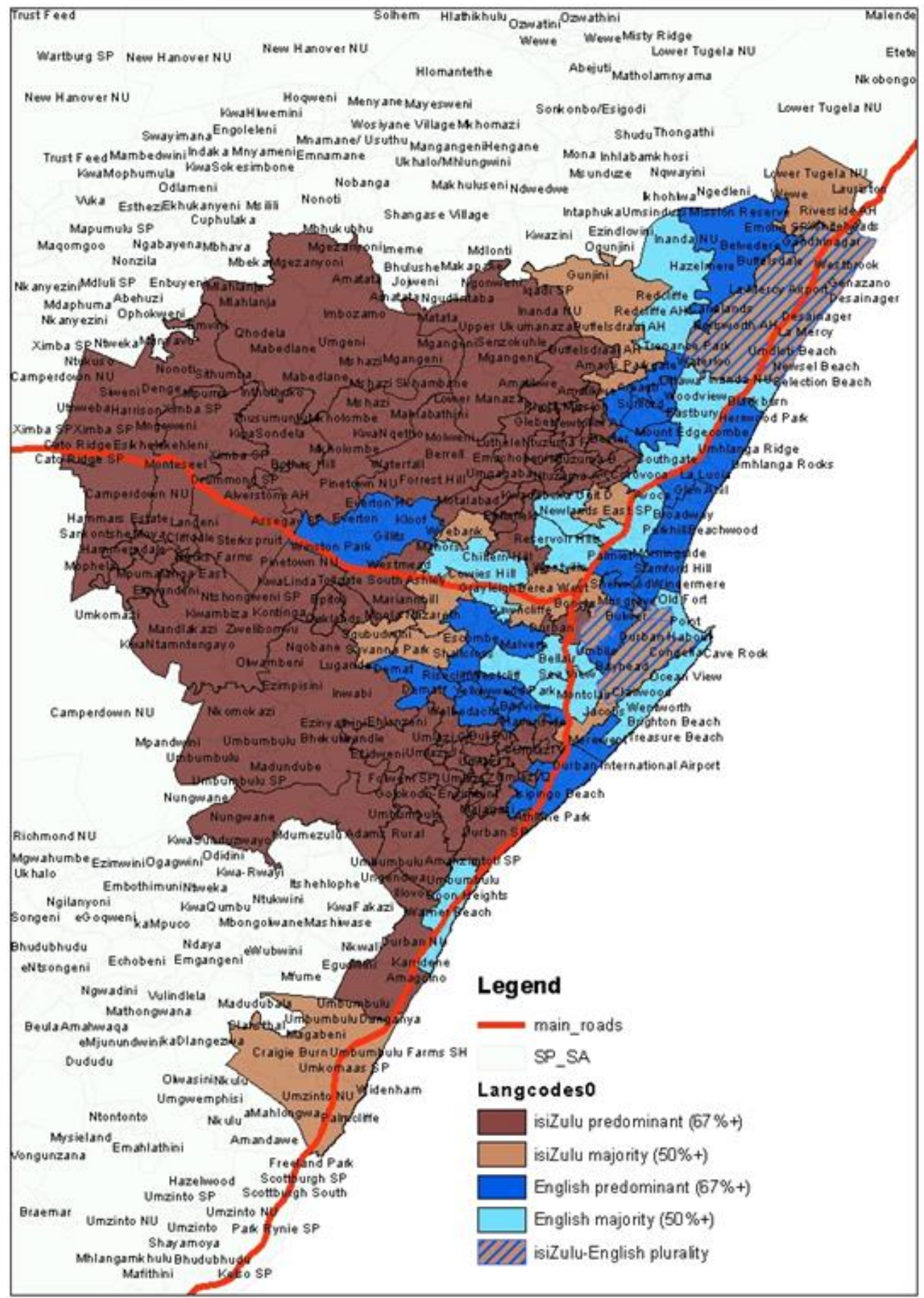

Figure 3: Household languages in eThekwini (200I Census) 


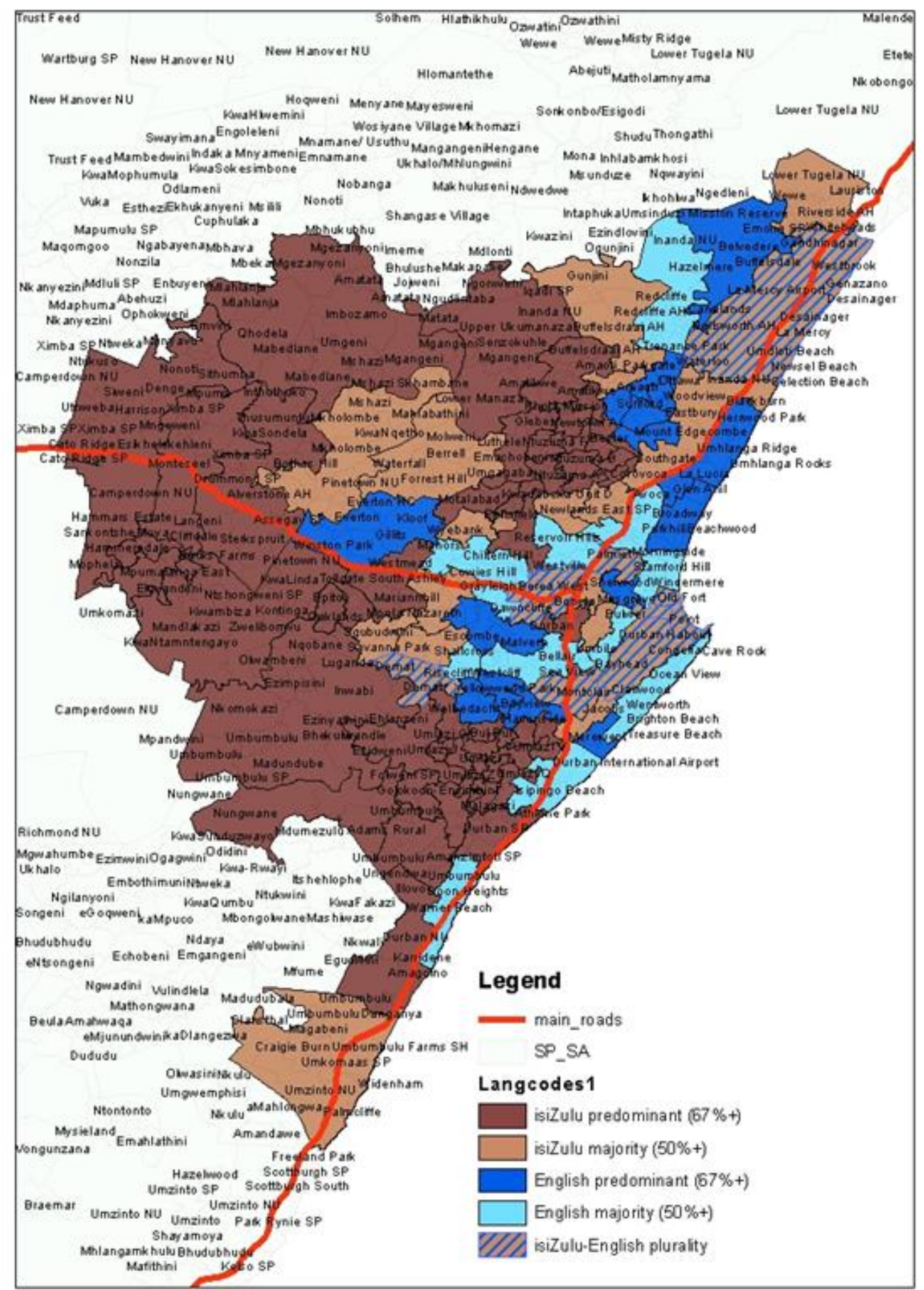

Figure 4: Household languages in eThekwini (20I I Census)

\section{Upward mobility and residential space in} eThekwini.

We categorise each of the seven selected study areas as higher or lower in terms of socio-economic status ('SE status') by comparing their status to that of the metro as a whole. Calculations are made on the basis of two variables: (I) the proportion of adults reporting post-matric educational qualifications; and (2) the proportion of adults reporting individual incomes exceeding that of R/2 800pm in $201 \mathrm{I}$. Accordingly, SE status refers to the magnitude of the higher socio-economic (SE) grouping among all adults in case study areas. Two case studies - UmbumbuluNkomokazi and Umgeni-Imbozamo - fell into the lower socio-economic status range; three case studies into the middle range (two we categorise as middle/lower since their scores albeit close to the metro averages, are slightly less and one 'higher/middle' slightly more); and two case studies Gillits-Kloof and Umhlanga - fell into the higher SE range (see Table 2). 
African Population Studies, Vol 30, No 2, 2016

Table 2: Main household languages spoken and socio-economic status of the seven sub-metropolitan case studies in eThekwini

\begin{tabular}{|c|c|c|c|c|c|c|c|c|}
\hline CASE STUDIES & $\begin{array}{l}\text { Metro } \\
\text { eThekwini }\end{array}$ & I. Gillitts-Kloof & $\begin{array}{l}\text { 2. Umdloti- } \\
\text { Tongaat }\end{array}$ & $\begin{array}{l}\text { 3.Umbumbulu- } \\
\text { Nkomokazi }\end{array}$ & $\begin{array}{l}\text { 4.Westcliff- } \\
\text { Bayview }\end{array}$ & 5. Umhlanga & $\begin{array}{l}\text { 6. Craigieburn- } \\
\text { Umkomaas }\end{array}$ & $\begin{array}{l}\text { 7. Umgeni- } \\
\text { Imbozamo }\end{array}$ \\
\hline $\begin{array}{l}\text { Language } \\
\text { Shift over I 5yrs } \\
\text { |996- 20I। }\end{array}$ & $\begin{array}{l}\text { isiZulu 57.I- } \\
58.8 \% \\
\text { English 35.8- } \\
29.0 \%\end{array}$ & $\begin{array}{l}\text { English } \\
\text { Predominant } \\
\text { No shift }\end{array}$ & $\begin{array}{l}\text { Shift English } \\
\text { Predominant to } \\
\text { isiZulu-English } \\
\text { mix }\end{array}$ & $\begin{array}{l}\text { isiZulu } \\
\text { Predominant } \\
\text { No shift }\end{array}$ & $\begin{array}{l}\text { English } \\
\text { Predominant } \\
\text { No shift }\end{array}$ & $\begin{array}{l}\text { English } \\
\text { Predominant } \\
\text { No shift }\end{array}$ & $\begin{array}{l}\text { isiZulu } \\
\text { Majoritarian } \\
\text { No shift }\end{array}$ & $\begin{array}{l}\text { isiZulu } \\
\text { Predominant } \\
\text { No shift }\end{array}$ \\
\hline $\begin{array}{l}2011 \text { two main } \\
\text { languages spoken \% }\end{array}$ & $\begin{array}{l}\text { Z: } 58.8 \% \\
\text { E; } 29.0 \%\end{array}$ & E: $80.7 \%$ Z:9.1\% & E: $34 \% \quad Z: 49 \%$ & Z: 93\% E:2.0\% & $\begin{array}{l}\text { E: } 85 \% \\
Z: 9.0 \%\end{array}$ & E: 76\% Z:9\% & Z: 63\% E:27\% & $\begin{array}{l}\text { Z: } 93 \% \\
E: 3 \%\end{array}$ \\
\hline $\begin{array}{l}\text { I } 996 \text { two main } \\
\text { languages spoken \% }\end{array}$ & $\begin{array}{l}\text { Z: } 57.1 \% \\
E ; 35.8 \%\end{array}$ & $\begin{array}{l}E: 77.5 \% \\
Z: \mid 4.1 \%\end{array}$ & E: 73\% Z:I6.0\% & $\begin{array}{l}\text { Z: } 98 \% \quad E: \\
0 \%\end{array}$ & E: 89\% Z:7\% & E: 75\% Z:1\% & $Z: 56 \% \quad E: 38 \%$ & $\mathrm{Z}: 98 \% \quad \mathrm{E}: 0 \%$ \\
\hline Socio-economicstatus & & Higher & Higher/Middle & Lower & Middle/Lower & Higher & Middle/Lower & Lower \\
\hline 20II Post matricScore & $11.5 \%$ & 46.1 & 14.2 & $1.9 \%$ & $8.1 \%$ & $44.3 \%$ & $7.8 \%$ & $2.2 \%$ \\
\hline 2001 Post matricScore & $9.3 \%$ & 37.9 & 14.7 & $1.8 \%$ & $7.3 \%$ & $34.4 \%$ & $6.9 \%$ & $1.6 \%$ \\
\hline $\begin{array}{l}\text { Improvement Post } \\
\text { matric } \% 2001 \text { - } 2011\end{array}$ & $2.2 \%$ & 8.2 & -0.5 & $0.1 \%$ & $0.8 \%$ & $9.9 \%$ & $0.9 \%$ & $0.6 \%$ \\
\hline $\begin{array}{l}201 \mathrm{I} \text { Indiv income(> RI2 } \\
800 \mathrm{pm})\end{array}$ & $7.4 \%$ & 41.6 & 9.8 & $0.9 \%$ & $5.8 \%$ & $44.2 \%$ & $5.3 \%$ & $1.1 \%$ \\
\hline $\begin{array}{l}200 \text { I Indiv inc(> } \\
\text { R6400pm) }\end{array}$ & $5.5 \%$ & 29.1 & 9.6 & $0.2 \%$ & $3.9 \%$ & $34.6 \%$ & $4.1 \%$ & $0.2 \%$ \\
\hline $\begin{array}{l}\text { Improvement \%higher } \\
\text { inc earners200I - 20II }\end{array}$ & $1.9 \%$ & $12.5 \%$ & $0.2 \%$ & $0.7 \%$ & $1.9 \%$ & $9.5 \%$ & $1.2 \%$ & $0.9 \%$ \\
\hline
\end{tabular}

Sources: 1996, 2001, 201I SA census 
Having established the relative socio-economic status of each case study area in $201 \mathrm{I}$, we repeated the process for $200 \mathrm{I}$ and then calculated the intercensus change for each of the variables ${ }^{8}$. We then compared the case study areas, both in terms of their recent status (20II) and in terms of changes during the inter-census decade of 200I-20II. On the basis of these calculations, three results stand out.

In the first place, within six of the seven case study areas as well as within the metro as a whole, both SE status indicators have improved. This suggests that a rise in the relative size of the more privileged section of the resident ward population has taken place virtually across the board in eThekwini. The only exception is Umdloti-Tongaat where there is a slight drop in the proportion of adults with post-matric qualification, due in all probability, to the in-migration from beyond the metro's boundaries of Zuluspeakers without such qualifications and intent on accessing better municipal services rather than work opportunities for which such qualifications are typically needed.

Secondly, no case study area changed its relative socio-economic status between $200 \mathrm{I}$ and 20II. Though one decade is not a long period during which to expect a significant shift in average socio-economic status of adults, certain of the cases have experienced high rates of in-migration (as we shall see below), rates that could cause such shifts.

Thirdly, the case studies that revealed the highest rise were the two cases in the higher SE range: Gillits-Kloof and Umhlanga both of which have remained predominantly English-speaking over this decade. In comparison with these two cases, the metro as a whole revealed significantly lower improvements of $2.2 \%$ (post matric qualifications) and $1.9 \%$ (higher individual income). Most revealingly however, all but one of the case study areas classified as lower and middle socio-economic status in 201 I revealed improvements lower than the city average between the 200 I and 20II censuses. The exception was the higher individual income score in the case of Westcliff Bayview which equalled that of the metro as a whole ( $1.9 \%$ increase).

\section{Race and residential space in eThekwini}

A simple albeit broad-brush way to track the extent to which eThekwini has addressed the legacies of the Group Areas Act - the apartheid legislation that defined racially segregated residential areas - is to consider how the racial profiles in our case study areas - based on the four race categories used in the censuses - have changed over the past fifteen years (Schensul \& Heller). In Table 3, ratios have been calculated for adult residents (aged 20+) in the years 1996, 2001 and 20II.

Statistics for the metro as a whole disclose that the proportion of African adults has increased steadily over the past fifteen years and the proportions of both Indian and White adults have decreased. In 2011 , some 7 out of 10 adults were African (and predominantly isiZulu-speaking) in eThekwini, some one out of five Indian and less than one in ten White, the latter two groupings being predominantly Englishspeaking. 
Table 3 Changing racial proportions of adults in eThekwini's 7 sub-metropolitan case studies

\begin{tabular}{|c|c|c|c|c|c|c|c|c|}
\hline CASE STUDIES & $\begin{array}{c}\text { Metro } \\
\text { eThekwini }\end{array}$ & \begin{tabular}{l}
\multicolumn{1}{c}{$l}$. \\
Gillitts-Kloof \\
HIGHER
\end{tabular} & $\begin{array}{l}2 . \\
\text { Umdloti- } \\
\text { Tongaat } \\
\text { MIDDLE }\end{array}$ & $\begin{array}{l}3 . \\
\text { Umbumbulu- } \\
\text { Nkomokazi } \\
\text { LOWER }\end{array}$ & $\begin{array}{l}4 . \\
\text { Westcliff- } \\
\text { Bayview } \\
\text { MIDDLE }\end{array}$ & $\begin{array}{l}5 . \\
\text { Umhlanga } \\
\text { HIGHER }\end{array}$ & $\begin{array}{l}6 . \\
\text { Craigieburn- } \\
\text { Umkomaas } \\
\text { MIDDLE }\end{array}$ & $\begin{array}{l}7 . \\
\text { Umgeni- } \\
\text { Imbozamo } \\
\quad \text { LOWER }\end{array}$ \\
\hline $\begin{array}{l}\text { Race proportions'African: } \\
\text { Coloured: Indian: White }\end{array}$ & $\begin{array}{l}\text { ADULTS } \\
20+\end{array}$ & & & & & & & \\
\hline 2011 ratios & $71: 3: 19: 8$ & $15: 1: 5: 79$ & $65: 1: 26: 8$ & $100: 0: 0: 0$ & $15: 1: 83: 0$ & $18: 2: 23: 57$ & $73: 1: 20: 7$ & 99:0:1:0 \\
\hline 2001 ratios & $66: 3: 21: 11$ & $17: 1: 10: 73$ & $57: 1: 37: 12$ & 100:0:0:0 & | I:1:88:0 & |3:1:1 |:74 & $67: 1: 24: 9$ & 100:0:0:0 \\
\hline 1996 ratios & $62: 3: 22: 13$ & 18:0:6:76 & $23: 1: 57: 19$ & $100: 0: 0: 0$ & 9:1:91:0 & $17: 0: 6: 77$ & $58: 1: 29: 13$ & 100:0:0:0 \\
\hline
\end{tabular}

Sources: 1996, 200I, 20II SA census

\footnotetext{
I 'Unspecified' responses excluded
} 
In 20 I I, all seven case study areas reveal a clear majority of adults from one racial category. In some cases however these proportions have changed little over the past fifteen years whereas in others there have been noteworthy shifts:

- Adults are virtually totally African in the two peri-urban peripheral cases with no change in racial proportions over the past fifteen years.

- There is a predominant African majority in Craigieburn-Umkomaas that grew from a significantly smaller proportion fifteen years ago and there has been a large increase in the African proportion (to 65\%) in UmdlotiTongaat from a small minority of the adult population (23\%) in 1996.

- The Indian proportion in Westcliff-Bayview has diminished somewhat but remains predominant $(83 \%)$ in 2011 whereas in three other cases - Umdloti-Tongaat, Umhlanga and Craigieburn-Umkomaas - Indians continue to make up a significant $(>20 \%)$ albeit dwindling minority.

- White adults make up the majority in two cases - Gillits-Kloof and Umhlanga. In the former case, not only do they make up the predominant proportion in 2011 but this proportion has risen over the past fifteen years to $79 \%$ in $201 \mathrm{l}$. In the latter case, on the other hand, the White proportion has been falling significantly (from $77 \%$ in 1996) and makes up $57 \%$ of adults in $201 \mathrm{I}$.

\section{Migration trends in the case study areas}

In order to provide a broad overview of migration into eThekwini and the seven sub-metropolitan case studies areas identified above, we first reflect on African internal migration streams toward Durban during the 1990s. Subsequently we turn to more recent trends.

During the mid-1990s, levels of mobility among the disadvantaged communities of KwaZulu-Natal were very high: it was estimated that some two-thirds of all African households had migrated at least once during their life cycle. The space economy of the province an enlarged version of the two development corridors comprising the N2 and N3 freeways in eThekwini - may also be envisaged as comprising two major development axes which intersect at the metro. The first runs up and down the coastline from the metro, thereby creating the densely settled corridors of the North and South Coasts. The second axis links the metro to Gauteng, bisecting the province along the Pietermaritzburg, Ladysmith and Newcastle corridor. Migrants capable of migrating over substantial distances sought out destination areas within or close to these axes (Bekker 2000). Since three of four households on the move were found to select destinations other than greater Durban in the mid-1990s, research identified the importance of economic infrastructure in this selection. As the availability of jobs for members of migrating families disappeared in Durban, migration streams tended to shift toward the second best option: a site for a homestead, water, electricity and accessible transport routes (Cross et al. 1996).

Within greater Durban (as it still was called at that time):

Levels of mobility are still very high in the metropolitan shack areas, and urban migration may be accelerating. Migration between localities within the metropolitan section makes up about 24 percent of the province's total migration. At the same time, there may be signs that part of the urban informal population could be stabilizing after the sudden expansion and decompression of urban shack settlement in the early 1990s (Cross et al. I996: I3).

Accordingly, prior to the establishment of the eThekwini municipality and its subsequent rationalisation of service delivery to all residents within its zone of jurisdiction, African migrants both in the province as well as in the metro lived unstable lives prone to movement and change, due to uncertain employment opportunities, inadequate infrastructure and recent high civil violence.

In turning our attention to more recent trends, we focus solely on adult migration streams during the census decade of 200 I-20 I I. Here adult residents in eThekwini have been defined as those who were at least 20 years old in 200 I. Using $201 \mathrm{I}$ census data, the 'adult population' was consequently restricted to people 30 years or older. Our analysis was limited by an important constraint: we were unable to explore mobility within the metro, as analysis was only possible at the inter-provincial level. We have consequently determined

(i) a combined figure for inter-census in-migration and intra-metropolitan migration both within the metro and within the seven case study areas;

(ii) in-migration rates into these areas from provinces other than KwaZulu-Natal, and

(iii)in addition, we have identified by racial grouping where migration streams into case study areas are higher than metro averages. (see summary in Table 4 below).

According to the 201 I Census, less than two adults out of ten (18\%) in eThekwini reported having made at least one residential move during the past decade. Such adult mobility which includes in-migration into the metro as well as intra-metro moves but not out- 
migration is relatively low when compared with (some of) the other metros. This may well point to the likelihood that the metro as well as the province exhibited a negative net migration profile over the past decade: inter-provincial flows over the 200I201 I decade recorded a net loss of 109899 persons in KwaZulu-Natal. (Provinces at a Glance 20 I I:20).

For eThekwini metro as a whole during this decade:

- In- and intra-migration flows of adult African (predominantly Zulu-speaking) at $16.6 \%$ were lower than the metro average at $18 \%$. This relatively low rate of mobility probably differs significantly from African mobility rates in the first inter-census period of 1996-200I when annual metro population growth rates - as we reported above - were substantially higher than during the later decade.

- Adult Indian residents in the metro were also less mobile, at $14.7 \%$, than the adult metro average (census 20II).

- White residents were highly mobile. This grouping revealed by far the highest proportion of adult residential moves: $35.3 \%$ of adult respondents reported a change of residence (whereas the proportion dropped to less than one out of five for both African and Indian adults) (census 20II).

- Foreign migrants entering eThekwini appear to have become an increasingly visible -albeit small - sub-population: some $6 \%$ of adults migrating into eThekwini over the past decade reported a foreign country as their sending area, of whom most hailed from Africa (census 20I I)
We now focus on adult migration into our seven sub-metropolitan case study areas during the last inter-census decade (see Table 4).

- In the first place, regarding isiZulu-speaking African migrants, it appears - in stark contrast to the turbulent 1990s - that the peri-urban predominant Zulu-speaking cases are particularly stable with less than one adult in fifty changing residence during the past decade.

- The two predominant English-speaking areas by contrast reveal high levels of in-migration, more than four persons in ten reporting a change of residence in Gillits-Kloof and in Umhlanga. On the other hand, Gillits-Kloof reveals higher than metro average in-migration streams from beyond KwaZulu-Natal whereas Umhlanga with high in-migration rates for all three races identified, has drawn migrants predominantly from metro and $K Z N$ provincial sending areas.

- Westcliff-Bayview, a majoritarian Indian case study, revealed in-migration trends about one half those of the metro as a whole and accordingly has probably become more settled than it would have been in the 1990s.

- Finally, in Umdloti-Tongaat in the far north and Craigieburn-Umkomaas in the far south of the metro, high in-migration rates were identified. In the former case these high trends were apparent among Africans and Whites whereas in the second case, they were apparent among Africans and Indians. Both case study areas have experienced recent economic and residential developments more rapid than in many other wards of eThekwini. 
African Population Studies, Vol 30, No 2, 2016

Table 4 Changing in- and intra-migration trends of adults in eThekwini's 7 sub-metropolitan case studies

\begin{tabular}{|c|c|c|c|c|c|c|c|c|}
\hline $\begin{array}{l}\text { CASE STUDIES } \\
\text { SE Status }\end{array}$ & $\begin{array}{l}\text { Metro } \\
\text { eThekwini }\end{array}$ & \begin{tabular}{l}
\multicolumn{1}{c}{ I } \\
Gillitts-Kloof \\
HIGHER
\end{tabular} & \begin{tabular}{l}
\multicolumn{1}{c}{2} \\
Umdloti- \\
Tongaat \\
MIDDLE
\end{tabular} & $\begin{array}{l}\text { U } \\
\begin{array}{l}\text { Umbumbulu- } \\
\text { Nkomokazi }\end{array} \\
\text { LOWER }\end{array}$ & $\begin{array}{l}\text { 4 } \\
\text { Westcliff- } \\
\text { Bayview } \\
\text { MIDDLE }\end{array}$ & $\begin{array}{c}5 \\
\text { Umhlanga } \\
\text { HIGHER }\end{array}$ & $\begin{array}{l}\text { 6raigieburn- } \\
\text { Umkomaas } \\
\text { MIDDLE }\end{array}$ & $\begin{array}{l}7 \\
\text { Umgeni-Imbozamo } \\
\text { LOWER }\end{array}$ \\
\hline $\begin{array}{l}\text { In-migration } \\
\text { over the decade } \\
200 \mathrm{I}-20 \mathrm{II} \\
\text { Adults }(30+\text { in } \\
20 \mathrm{II})\end{array}$ & $\begin{array}{l}\text { ADULTS } \\
30+\end{array}$ & & & & & & & \\
\hline $\begin{array}{c}\text { In-migration } \\
\text { rates into eThekwini } \\
\text { and } \\
7 \text { cases: } \\
\text { \% total population } \\
30+ \\
\end{array}$ & $18 \%$ & $43 \%$ & $29 \%$ & $3 \%$ & $9.5 \%$ & $41 \%$ & $16 \%$ & $2 \%$ \\
\hline $\begin{array}{c}\text { In-migration } \\
\text { rates into eThekwini } \\
\text { from other RSA } \\
\text { provinces } \\
\text { (\% of total migration } \\
\text { population) } \\
\end{array}$ & $13 \%$ & $19 \% \uparrow$ & $18 \% \uparrow$ & $5 \% \downarrow$ & $6 \% \downarrow$ & $9 \% \downarrow$ & $21 \% \uparrow$ & $9 \% \downarrow$ \\
\hline $\begin{array}{c}\text { In-migration } \\
\text { rates by race: areas } \\
\text { where rates are } \\
\text { higher than the } \\
\text { metro average of } \\
18 \%\end{array}$ & & $\begin{array}{l}\text { White rate } \\
> \\
(45 \%)\end{array}$ & $\begin{array}{l}\text { African rate > } \\
(32 \%) \text { and } \\
\text { White rate > } \\
(45 \%)\end{array}$ & ------ & ------ & $\begin{array}{l}\text { African rate }> \\
(40 \%), \text { Indian } \\
\text { rate }>(47 \%), \\
\text { White rate }> \\
(40 \%)\end{array}$ & $\begin{array}{l}\text { African rate }> \\
(33 \%) \text { and Indian } \\
\text { rate }>(33 \%)\end{array}$ & ----- \\
\hline
\end{tabular}

Sources: 200 I \& 20II SA census 
While overall adult migration into and within eThekwini is calculated at $18 \%$, it is noteworthy that migration to the seven case study areas correlates with their relative SE status: the two higher SE areas have the highest in-migration rates, the middle SE status cases have in-migration rate closer to that of the metro, whereas the two lower SE status areas all have in-migration levels radically lower than the metro average. It would seem therefore that geographical mobility (migration) and upward social mobility are linked, with the latter tending to facilitate the former. Adult migrants with resources and a wider range of residential options, tend to select higher SE areas (or to leave the metro for other destinations). On the other hand, adults in the lower SE case study areas are constrained by income and other material considerations.

\section{Conclusion}

eThekwini is a metro that has over the past fifteen years knitted together

- the former Natal province and former KwaZulu homeland regions,

- former Coloured, Indian and White Group Areas together with African townships, informal settlements and tribal areas, and

- rural, peri-urban and urban spaces.

$\bullet$

We first summarize the extent to which language, SE status, race and migration appear to have played a role in planned and unintended changes to the lives and living conditions of the metro's adult residents over this period. Subsequently, we will combine these factors into a more general conclusion regarding the role language has played recently in eThekwini.

isiZulu is the most widely spoken household language in the metro and dominates in a peri-urban interior semicircle from Inanda to Umbumbulu, covering more than half the surface area of eThekwini. This area which coincides with that part of the former KwaZulu homeland incorporated into the metro is also administered in parallel by traditional and metro authority, in which both amakhosi and ward councillors operate. In our two case studies in this region - Umbumbulu-Nkomokazi and Umgeni-Imbozamo - isiZulu has remained the household language (93\% in both cases in $20 \mathrm{ll}$ ).

The two racial minorities in the metro, Indians and Whites, make up the large majority of Englishspeaking adults. Though there has been little change in this language identity over the past fifteen years, the dramatic process of Anglicization of Indian residents a few decades early is worth underlining.
There is no indication in our data of an equivalent process among isiZulu-speakers.

Though continuity rather than change appears to be the norm regarding household language in eThekwini, there are possible pointers toward Anglicization among the isiZulu-speaking African adult population. In the two predominantly Englishspeaking case studies - Gillitts-Kloof and Umhlanga a comparison of the proportions reporting being isiZulu-speaking ( $9 \%$ in both cases in $20 \mathrm{II})$ to those being African (15\% and $18 \%$ in $201 \mathrm{I}$, respectively) suggests that there is a measure of Anglicization among local Africans who probably make up a substantial proportion of these minorities. Correspondingly, in the two case studies in the periurban interior - Umbumbulu-Nkomokazi and Umgeni-Imbozamo - the emergence of a small proportion of English-speakers is identifiable ( $2 \%$ and $3 \%$ in 20II, respectively).

The two variables we selected - post-matric qualifications and individual income above a certain threshold - were employed to identify the magnitude of the higher socio-economic (SE) grouping among all adults in case study areas. Our data suggest that this higher SE grouping - probably comprising some 10\% of the adult metro population in $20 \mathrm{II}$ - has increased a little over the past ten years. These data also point to the fact that the case studies revealing the highest improvement were the two located in the higher SE range: Gillits-Kloof and Umhlanga. Most revealingly moreover all the case studies classified as lower and middle socio-economic status in 201 I disclosed increases lower than - in one case equal to - the city average between the $200 \mathrm{I}$ and $20 \mathrm{II}$ censuses. In short, it appears that substantial improvement in SE status took place only in higher SE status areas.

With regard to changes in the racial composition of different areas of the metro, it is striking to report that in all our seven cases studies in 20 II, a clear majority of adults from one racial category was found. In addition, over the period 1996-20II, the same racial majority was maintained in all but one case: Umdloti-Tongaat. Since the proportion of African adults has increased significantly in the metro as a whole over the past fifteen years, it is not surprising that African adult majorities were maintained in peri-urban (former KwaZulu homeland) areas. They also increased their proportions (some as minorities) in all other case studies except Gillits-Kloof where the proportion of white adults rose from $76 \%$ to $79 \%$.

The exceptional case of Umdloti-Tongaat in the far north is worth some further discussion. Its adult racial composition in 1996 was 23\% African, $57 \%$ Indian and $19 \%$ White. Fifteen years later, this had changed to $65 \%$ African, $26 \%$ Indian and $8 \%$ White. Probable 
factors underlying this change are the search by Africans outside the metro for residence within it - in an area that fell within the former province of Natal rather than the former homeland of KwaZulu - so as to be able to access superior municipal services. In the second place, both middle class Indians and Whites may have left the ward for more up-market and more racially and linguistically homogenous destination areas, both within the metro as well as without.

Two results associated with migration into and within the metro stand out. In the first place, less than two adults out of ten in eThekwini reported having made at least one residential move during the past decade, a proportion that includes in-migration into the metro as well as intra-metro moves. This is relatively low. African and Indian adults reported migration rates lower than this metro average whilst the White adult minority were highly mobile: more than three in ten White adults reported at least one move. In the second place, it appears - in stark contrast to the turbulent 1990s when intrametropolitan migration was extremely high - that isiZulu-speaking African adults residing in the periurban metro region are particularly stable with less than one adult in fifty reporting a change of residence during the past decade. A major reason may be found in the provision by the metro of improved municipal services (water, sewage, electricity and transport in particular). That these are delivered to peri-urban wards where traditional authority takes responsibility for land tenure (and other) issues whilst the metro authority takes responsibility for service delivery points to an attractive living environment for poor isiZulu-speaking households - albeit not one that is fully sustainable since municipal services charges are emerging as a major challenge both for residents and for municipality.

English appears in eThekwini to be the household language of the social elite as well as the language of upward mobility and empowerment. The Anglicization of Indian adult residents over the past half century bears testimony to this resource as well as to the importance that primary and secondary education play in gaining access to it. Simultaneously, the isiZulu-speaking households living in the periurban (former homeland) wards of the metro though receiving improved municipal services appear the least likely to have access to it. On the other hand, those isiZulu speakers who have moved to wards of higher socio-economic status - where they find themselves living with English-speaking racial minorities - appear to have a better chance of accessing English as a resource.

In short, trends toward higher SE status among adults at ward level overlap broadly with trends toward reporting English as the household language this complex interplay implies reciprocity: accessing English assists in upward mobility and upward mobility enables families to take up residence in wards where accessing English is easier. Nonetheless, the large majority of adult Africans reported in 201 I that they spoke isiZulu or a related Nguni language at home and were living in wards that were predominantly African. English is far from becoming a lingua franca in the metro.

\section{Bibliography}

Ballard, R., D. Bonnin, J. Robinson and T. 2007. "Development and New Forms of Democracy in eThekwini" Urban Forum 18: 265-287.

Bekker, S. 2000. "Internal migration and infrastructural provision" Regional Science Association International Symposium. Conference Proceedings on CD, PE Technikon, Port Elizabeth.

Bekker S. and Humphries, R. 1985. From control to confusion: the changing role of Administration Boards in South Africa 1971-1983. Pietermaritzburg: Shuter and Shooter.

Bekker S. \& Louw, A. 1992. "Capturing the Event: Conflict Trends in the Natal Region 1986 - 1992" Indicator Issue Focus, University of Natal.

Casale, D. and Posel, D. 20II. "English language proficiency and earnings in a developing country: The case of South Africa" Journal of SocioEconomics, 40: 385-393.

Cross C., Mlambo, N, Mngadi, T, Pretorius, H, Mbhele, T and Bekker, S. 1996. "Locating productive small farmers: population shifts and land reform on the Eastern Seaboard of South Africa" Working Paper Series, Development Bank of Southern Africa.

Davies, R. and Rajah, D. 1965. "The Durban C.B.D.: boundary delimitation and racial dualism" South African Geographical Journal 47: 45-58.

Desai, A. 2014. The Archi-texture of Durban: a Skapie's Guide. Durban: Madiba Publishers.

"Draft Integrated Development Plan 5 Year Plan: 2012/13 to 2016/17". 2013. eThekwini Municipality

"Economic Review for the eThekwini Municipal region 2010/20II". 2012. Urban-Econ Development Economists, eThekwini Municipality.

Freund, W. 2007. The African City. Cambridge: Cambridge University Press.

Freund,W. \& Padayachee, V. 2002. (D)urban Vortex: South African City in Transition. University of Natal Press: Durban. 
Hill, L. and Bekker, S. 20I4. "Language, residential space and inequality in Cape Town: Broad-brush profiles and trends" African Population Studies (Supplement on Population Issues in South Africa) 28, (I): 648-660.

Kuper, L., Watts, H. and Davies, R. 1958. Durban: a study in racial ecology. Jonathan Cape, London.

Maharaj, B. and Ramballi, K. 1998. "Local economic development strategies in an emerging democracy: the case of Durban in South Africa" Urban Studies 35, (I): | 3 |- 448.

Maylam, P. \& Edwards, I. 1996. The People's City: African life in twentieth-century Durban. University of Natal Press: Durban.

Mestrie, R. 2004. "From second language to first language: Indian South African English" in R. Mestrie (ed.) Language in South Africa. Cambridge University Press.

Palmary, I. 2004. "Traditional Leaders in the eThekwini Metropolitan Region: Their role in crime prevention and safety promotion" Centre for the Study of Violence and Reconciliation and Midlands Women's Group, Durban.

Schensul, D. and Heller, P. 20I I. "Legacies, Change and Transformation in the Post-Apartheid City: Towards an Urban Sociological Cartography" International Journal of Urban and Regional Research, 35, (I): 78-109.

Seekings, J. and Nattrass, N. 2005. Class, race and inequality in South Africa. Yale University Press, New Haven.

Stats SA. 2012. "Provinces at a glance, Census 20II", Report 03-0I-43. Pretoria.

\section{Notes}

${ }^{1}$ Corresponding author

2 Source: Development Planning, Environment \& Management Unit, eThekwini Municipality. 3

Source:

http://www.kzncogta.gov.za/Municipalities/eThekwiniMunicipal ity.aspx accessed I5 December 2014.

4 Since residents classified as "coloured" make up a small proportion of this population, they have been excluded from the analysis.

5 Economic Review for the eThekwini Municipal region 2010/201I. Durban: Urban-Econ

Development Economists

${ }^{6}$ Sources: Kuper, Watts \& Davies 1958; and Census 20I I, Stats SA.

7 Personal communication, Ms Dudu Khumalo, November 2014.

8 For the sake of simplicity, we do not repeat this exercise for the 1996-200I inter-census period. 